\title{
In the Spirit of Oil: Unintended Flows and Leaky Lives in Northeastern Ecuador
}

\author{
Stine Kroijer
}

Throughout the Americas, agroindustry, oil, gas, and mining projects have pushed the extractive frontier deeper into indigenous territories, more often than not with devastating social and environmental effects (Sawyer 2004, 2015; Bebbington 2012; Bebbington and Bury 2013; Hindery 2013). In northeastern Ecuador, exploration for oil began more than 40 years ago, when Texaco initiated operations in what was represented by the Ecuadorian state as an uninhabited, empty hinterland (Whitten 1978, 1981; Wasserstrom and Southgate 2013). Nonetheless, these 'empty' lands and forests were the home of the Cofán, Siona, Secoya, and Huaorani indigenous peoples. The intended and unintended consequences of oil exploitation-from contamination to colonisation and deforestation-have unavoidably led indigenous communities in the area to seek out their own strategies for coping and living their lives with oil. The chapter asks: how does a community uphold a sense of control over their lives in the encounter with extractivist policies?

\footnotetext{
S. Krøijer $(\bowtie)$

University of Copenhagen, Copenhagen, Denmark

e-mail: stine.kroijer@anthro.ku.dk

(C) The Author(s) 2019

C. Vindal Ødegaard, J. J. Rivera Andía (eds.), Indigenous Life

Projects and Extractivism, Approaches to Social Inequality and

Difference, https://doi.org/10.1007/978-3-319-93435-8_4
}

95 
This chapter is based on recurring fieldwork among the Ecuadorian Secoya, now self-denominated the Sieko-pai, a western Tucano-speaking people who live along the Aguarico River in the northwestern corner of the Amazon Basin (Vickers 1989a). When I first arrived in 2000, the community members in San Pablo Katëtsiaya, the largest of four Secoya villages in Ecuador, were already well acquainted with oil exploitation, and several elders figured among the plaintiffs in the ongoing international lawsuit against Chevron-Texaco for the contamination caused during their operations in the area during the 1970s and 1980s (Kimerling 1993; Sawyer 2001, 2004, 2015; Barrett 2014). I was interested in understanding how these experiences, and other past encounters with powerful 'others,' were brought to bear on their ongoing talks with Occidental Petroleum Company, a US-based oil company, which at the time held the rights to exploit resources below Secoya territory (Krøijer 2003, 2017). Over the next many years, I worked with the Secoya indigenous organisations in Peru and Ecuador on a binational land rights claim which would enable them to (re)establish a continuous binational territory in a border area historically torn by war, colonisation, and the effects of the rubber boom in the Upper Amazon (Casement 1913; Hardenburg 1913; Taussig 1987; Vickers 1989a; Santos-Granero and Barclay 2002; Wasserstrom 2014). When I returned again for long-term fieldwork in 2014-15, the Secoya were in talks with a Chinese-owned company, Andes Petrol Ecuador Ltd, which was bent on drilling two exploratory wells in the immediate vicinity of San Pablo Katëtsiaya. A longitudinal perspective has enabled me to appreciate how the Secoya, sometimes in seemingly contradictory ways, do their best to retain a sense of control and self-determination in a world of profound transformations and how, in such contexts, it becomes the work of shamans and local leaders to control unintended flows and transformations (see also Krøijer 2017).

This chapter takes its conceptual point of departure in the Secoya word for oil, wëhue - literally breach or leak in pai-koka —a linguistic and conceptual invention born of oil exploitation. I take the leaky quality of oil as my analytical lens for questioning the widespread academic and political discourse about extractive enclaves by which extractive industries carve out spaces of sovereignty in independent states (Ferguson 2005; Bebbington 2012; Guzmán-Gallegos 2012). This notion has been employed by companies to suggest that their impacts can be spatially contained (see Hindery 2013). I show how resource extraction ties into the Secoya's view of the cosmos as being in constant transformation; hence, how leaky matters and 
uncontrolled flows become matters of special concern. In so doing, the chapter speaks to an ongoing theoretical debate concerning the alleged 'essentialism' of the ontological turn in anthropology (Heywood 2012; Pedersen 2012; Bessire 2014; Vigh and Sausdal 2014; Cepek 2016; Holbraad and Pedersen 2017) and how the concern for ontological questions in the context of resource extraction is sometimes-mistakenlytaken as an argument for the claim that oil is a spirit for (at least some) indigenous peoples in the Ecuadorian Amazon (Cepek 2016). Rather than taking this mistaken perception as the point of departure for a critique of an anthropological interest in ontological questions (see Cepek 2016), I argue that oil is dealt with in the spirit of oil, namely as a matter of uncontrolled transformation. The leakiness of oil is, in other words, the only essence at stake. Analogous to Pedersen (2014), I show how unintended flows and transformations are dealt with through diverse strategies of containment and control. It is through attempts to steer, contain, and control leaky material flows around resource extraction that the Secoya carve out a space of self-determination on their land.

\section{Oil and Leaky Enclaves in Ecuador}

In 1964, the Texaco-Gulf Consortium obtained a 40-year contract to an area covering approximately 1.5 million hectares in northeastern Ecuador. Between 1972 and 1991, the company produced more than 1.4 billion barrels of crude oil from 238 wells; when this cornerstone of 'modernization and development' left the country in 1992, more than 600 open-waste pits were left behind (Kimerling 1993: 21-22; Sawyer 2001: 162) leaking crude oil and toxic production water into waterways. When the Secoya were moved to their current location by the Summer Institute of Linguistics (SIL) in 1973 (Vickers 1989a), they saw the area as an unending, fertile, and abundant forest (ibid.; Krøijer 2017), but soon they would find themselves in the frenzy of oil exploitation. Most of the adult Secoya men were hired by Texaco for clearing a grid of seismic paths cutting through the forests as well as for other manual labour. Families would frequently receive gifts and food—such as rice, sugar, and cooking oil—from company workers passing through San Pablo to enable the frictionless access and uninterrupted presence of the company (Krøijer 2003). Texaco called their policy for community relations 'the good neighbour,' implying that they had no formal obligations to the indigenous inhabitants in the area but intended to develop friendly relations with the population (Wray 2000: 46). 
Apart from the military garrisons, the Ecuadorian state had little presence in the zone during the 1970s, but delegated the role of spearhead of civilisation and development to Texaco and to the missionaries from SIL who had settled in the village. The evangelical missionaries, together with Texaco, were the only institutional interlocutors who mediated the Secoya's access to desired goods from the outside. At first glance, therefore, Texaco's activities in Ecuador lived up to standard definitions of an enclave economy, in reality operating as a state within the state (Weisskoff and Wolf 1977; Ferguson 2005; Hindery 2013). This not only undermines the government's ability to foster inclusive development for its population but also erodes indigenous peoples' sense of territorial sovereignty and self-determination (Wray 2000; Bebbington 2012; Guzmán-Gallegos 2012) as they only have limited influence on the extractive activities taking place on their land. ${ }^{2}$ Even though the Secoya hold territorial rights, this right does not include property rights to subsurface resources, which across the world and with few exceptions belong to the nation-state but can be licensed to private companies.

In the 1970s, however, Ecuador saw a first surge of resource nationalism, headed by successive military governments which reclaimed state ownership over underground resources, established a state oil company, and renegotiated contracts to gain more control over the booming oil sector. Texaco's contract was cut to 20 years and the concession reduced to approximately 500,000 hectares (Wray 2000; Gordillo García 2005; Perreault and Valdivia 2010; Rosales 2017). While Texaco's oil production generated a profit of approximately USD 25 billion over a 20 -year period, the Amazon region became strategically important to the national economy. Oil exports for decades covered up to 50 per cent of the state budget (Wray 2000: 24), but for local inhabitants such as the Secoya, living around production sites and along contaminated waterways, oil production had few tangible benefits. As histories from this period attest, the Secoya felt taken by surprise, overwhelmed and abandoned by the state; the effects were experienced as a threat to their physical existence. This sense of threat was epitomised by the 1987 earthquake that caused a pipeline rupture which turned the Aguarico River black with oil and heavily impacted riverine life. Inexperience with contamination caused several human deaths from drinking or bathing in the river (Krøijer 2003, 2017).

In response to colonisation and increased pressure on the land, which to the Secoya continue to be some of the most troublesome effects of oil exploitation and associated infrastructure development, the Siona and 
Secoya formed an organisation in 1976 demanding territorial rights along the Aguarico and Cuyabeno Rivers. ${ }^{3}$ To embark on this process, they had to seek out new allies, as the local representatives of SIL 'did not see it as their role to help us in politics,' as a Secoya leader would later explain. Over the coming years, the Organization of the Siona and Secoya of Ecuador (OISSE, later OISE) joined forces with the nascent national indigenous movement (Vickers 1989b). At first, the Secoya only gained land rights to a small plot of land around the village of San Pablo, as they were considered to be peasants, but, by 1990 , the land title was expanded to 42,614 hectares (NASIEPAI 2014: 28).

In 1993, the Secoya joined a class action lawsuit against Texaco, which was filed in New York, to hold the company accountable for the devastating effects of oil exploitation. The state oil company, PetroEcuador, took over the production of the Sacha and Shushufindi oil camps closest to Secoya territory as well as the neglectful industrial practices, and much of the following legal battle has concerned who was in fact responsible for the undeniable contamination. So far the Secoya have seen little compensation, but contrary to the academic preference for histories about either heroic resistance or total devastation (Cepek 2009), it must be observed that the profound transformations of the environment and social life did not prevent them from acting on their situation. Even though the Secoya never resisted oil exploration, or saw it as within their power to prevent further oil development, they have continuously tried to steer the transformations and continuously engaged in dialogue and consultation processes with the stream of companies that have explored for oil on their land during the past 40 years. These companies have demonstrated increasing interest in engaging indigenous peoples in 'participatory processes' (cf. Li 2015).

In light of the above, the enclave metaphor, if applied in the context of oil exploitation on indigenous land (Guzmán-Gallegos 2012), can wrongly give the impression that the production and its effects are contained. The concept is appropriate insofar as the Ecuadorian government transfers the right to explore for oil within a concession to a private company, that is, to a bounded area that neither corresponds to indigenous concepts of territoriality nor to the administrative boundaries within states (ibid.: 162). It is equally or even more relevant, however, to understand how such enclaves leak, as onshore production sites are almost never completely separated from ongoing life in local and indigenous communities, who do their best to govern the material spill-over - for example, of money, gifts, and contamination-as 
well as other, unintended effects. As argued by Ødegaard in her chapter on Peruvian contrabandistas (this volume), people may redirect such flows or engage them in other life-making projects.

To appreciate the efforts at containing and steering flows from enclaves, it is worthwhile to look briefly into the Secoya's second major encounter with a US oil company. In the mid-1980s, new possibilities for foreign investments were opened in the oil sector in Ecuador (Perreault and Valdivia 2010: 691) and, between 1985 and 1995, the Ecuadorian Ministry of Energy and Mines held eight rounds of competitive tendering among foreign companies (Wray 2000: 29). Occidental Petroleum and Production Company (Occidental) took over a concession known as Block 15 , in 1985, but the Secoya knew little of this bureaucratic transfer until 1996, when a team of researchers preparing the environmental impact study made their appearance in their midst, backed by soldiers from the military and a strong community relations team, which intended to 'work the needs' of the Secoya communities to secure their signature on a contract allowing all future oil activities on their land (Vickers 1998; Krøijer 2017: 11). Occidental repeated Texaco's 'good neighbour' slogan in the title of their community relations strategy. At first, the team did its best to 'work the divisions' between Secoya families and between communities by offering money to individuals (cf. Guzmán-Gallegos 2012) and threating with expropriation of the land. Nevertheless, Occidental soon had to realise that the Secoya had become better organised, which played out not only as having better knowledge of their rights but also as better access to counselling and ability to control and formalise the interactions between company and community representatives.

Through several rounds of negotiations in Quito concerning the topographic, seismic, and exploratory phases of oil exploitation, the Secoya managed to negotiate compensations that they were largely satisfied with. Apart from the compensation funds, the signing of a Code of Conduct (OEPC 2000), which regulated the procedures of the negotiation process, was of particular importance to the Secoya. According to this, the company was only entitled to approach the communities through meetings with a dialogue committee appointed by the general assembly of the Secoya organisation. Later, when production went into the exploratory phase, the Code of Conduct also regulated the presence and movement of workers within the territory; they could not build new roads, come close to human settlements, or physically leave the oil camp in any way, and both equipment and personnel had to be moved to and from the oil platforms 
by helicopter. With the assistance of a lawyer from the Confederation of Indigenous Nationalities in Ecuador (CONAIE) and biologists from an Ecuadorian NGO, the agreements were monitored carefully. The Secoya also formed their own monitoring group with support from the NGO, which went to the platforms on a regular basis to perform inspections and take water samples from the surrounding creeks and streams. The intended seclusion was not always upheld in practice-hunters would sometimes sell game to the camp kitchen, there were stories of women having love affairs with workers, and after long periods of rain where the helicopter could not access the platform, workers would sometimes be allowed to walk to the nearest village to be transported away by boat-but on the whole the process reinforced a sense of being at least in partial control of events. What caused most upheaval was the flow of money, especially OISE's decision to distribute the compensation directly to all Secoya families. Some invested in education or in small businesses, but it also enrolled some community members in a personalised boom-and-burst economy: drinking, haphazard purchases, and daring economic ventures, which at least on one occasion distorted the sense of shared ownership of the land, creating quarrels and ongoing internal disputes, which only abated long after Occidental failed to find commercially sound quantities of oil, the exploratory wells were sealed, and the source of money ran dry (Krøijer 2003).

Today, Ecuador presents a valuable opportunity to reevaluate the idea of enclave economies. First, the emergence of a 'neo-extractivist' government led by President Rafael Correa has again increased the state's role in extraction as well as the investments of revenues in infrastructure and (in a more) inclusive development (Perreault and Valdivia 2010; Gudynas 2014). In the Secoya's view, this turn of government has only to a limited extent benefited them; they were, moreover, displeased with the decision to revoke Occidental's licence in 2006, after the company was accused of having transferred part of its oilfield to another company without government authorisation. ${ }^{4}$ Even under the New Left, sites of extraction often continue to be characterised by weak state presence, though my more recent fieldwork on northeastern Ecuador also shows that there is a growing recognition among the Secoya of the state as a key interlocutor in resource extraction (cf. Reider and Wasserstrom 2013). Second, regardless of state presence, companies are no longer unfettered in their efforts to reconfigure territories for capital accumulation, nor are production sites secluded from or unconnected to the surrounding world. As the above examples illustrate, production sites not only produce leaky substances, 
such as oil and contaminated production water, but money also 'leaks' and generates its own intended and unintended effects, as they are entangled in different and often awkward forms of collaboration (cf. Li 2015; Tsing 2005). These relational flows reconfigure the socio-environmental landscape but are also intersected both by the company's and the indigenous peoples' strategies of containment and control. Hence, the concept of 'enclaves' often seems to enclose the analysis itself by supposing seclusion and can become a political shield against furthering an understanding of how leaks produce new realities. The Secoya's word for oil, to which we shall now turn, has the quality of highlighting instead its leaky and transformational effects.

\section{LEAKY REALITIES}

We are sitting on the narrow porch outside Manatí's house on the bank of the Aguarico River discussing the plans of a Chinese-owned oil company, Andes Petrol Ecuador, to drill two exploratory oil wells in the immediate vicinity of San Pablo Katëtsiaya. Besides Manatí, who is the son of a late reknown shaman, Manatí's son Alberto and his grandson Hugo also participate in our conversation, which was sparked by a recent meeting in the Secoya organisation.

During the meeting in the small, shed-like office of the organisation, community members had gathered to see if they could reach a consensus on how to act. The condition of the office with its scattered white plastic chairs stood in stark contrast to the sea of new motorcycles and pickup trucks parked outside, most of which belonged to community members and were purchased with compensation money paid in the past. Most participants turned out to be in favour of Andes Petrol's plans, expressing anticipatory hopes for the benefits oil exploitation would bring in terms of jobs and monetary compensation. There were concerns, however, about the closeness of the wells to the village and the ability of the leaders to 'negotiate well,' as the company was again seen as trying to push through a fast and relentless 'consultation' process. In such meetings memories of Texaco were evoked to warn against the negative consequences of oil exploitation. Part of the meeting also consisted in a report back from the Ecuadorian lawyer in the Chevron-Texaco lawsuit, which had been shifted from the court in Lago Agrio, the centre of Texaco's Ecuadorian adventure, to Den Haag in Holland, and from there on to Canada and Argentina, where the plaintiffs hope to lay claim on Chevron's assets. Several Secoya 
elders were still part of the group of plaintiffs, but that did not prevent the organisation from simultaneously engaging in negotiations over new oil activities on their land. Some people attending the meeting expressed that they would be unable to prevent the plans of Andes Petrol because, as they rightly observed, the government had already received Chinese loans, which were to be repaid with oil deliveries. They might as well get the best out of it, they reasoned. And few could deny that many families were in dire need of an income, as most were unable to survive on subsistence agriculture and hunting in what was described as a territory marked by increasing scarcity.

Manatí and his extended family did not favour further oil exploitation. While looking over the river, Manatí vividly recounts how they got exhausted from the work journeys during the land delimitation process in the mid-1990s. Little did they know, he said, that they would not just be able to 'go someplace else' when the land got depleted as 'the forest was by now full of other people.' Hugo, Manatí's grandson, Hugo's wife Lucía, and their children were now among the young families who did not have use of the agreed 100 hectares for gardening as the previous generations had, due to population increase and scarcity of land. Most Secoya living in and around San Pablo relied almost entirely on purchased foods, especially rice, canned fish, oil, and sugar for their daily subsistence. Also, this afternoon, Manatí would complain that the territory had grown empty (poe'say'yo), with barren patches, little life, and few animals to hunt. The felling of the large slow-growing trees also meant that the wati (spirits or forest-beings) had abandoned the area around San Pablo and moved further away (Krøijer 2017). Contrary to the state's representation, in the 1960s of the Amazonian lowland as barren and ripe for colonisation, its new emptiness, in Manatí's optic, was full of people.

Some ten years ago, Manatí, his daughter, and a few other relatives had resumed the drinking of yagé (ayahuasca) on a regular basis, which had been banned by the SIL as well as the converted, evangelical community members, who also happened to hold the leading posts within the indigenous organisation. The death of Manatí's father, the renowned inti'ba'ikë (shaman-leader) Fernando Payaguaje (1994), had led to a situation of 'shamanism without shamans' (Brunelli 1996; Langdon 2016), and several community members tied the lack of animals to the lack of an able inti'ba'ikë to attract the game. Now, the drinking of yagé had become a modest source of income from international tourists and middle-class 
Ecuadorians who wished to use the hallucinogenic brew in what they consider to be their spiritual self-discovery. Moreover, the regular drinking of yagé had also enabled Manatí to resume the transiting of perspectives and exploration of the cosmos which his own father had been so famous for. While living in the house of his family, I had tapped into this knowledge about forest-beings in connection to a research project on the political lives of trees (Krøijer forthcoming). The shamanic practices of the Secoya share important features with other indigenous groups in the Amazon Basin (Viveiros de Castro 1998). This involves seeing all beings of the forests as persons, which the shaman, according to Manatí, 'is able to go visit' in order to 'live like they do' through the bodily metamorphosis assisted by yagé. Through bodily transformation, the shaman taps into the knowledge of these beings and comes to understand how the cosmos is 'essentially' transformational (Krøijer 2017).

'What is the word for oil in pai-koka?' I ask Manatí while leaning against the wall of his house, where the former bright pink painted walls were now peeling; suddenly realising that even though I had taken an acute interest in Secoya negotiations with oil companies, since my first fieldwork in 2000, I had never asked that question. 'Wëhue,' Alberto replies, and continues:

\begin{abstract}
Today we use the term nea wi'yape for the aceite [oil] that you buy in containers, the one that you use for mixing with gasoline for outboard motors, but this is a new word. We also still use the term wëhue, which means breach [derrame] or something that leaks.
\end{abstract}

'Did the Secoya know of oil before Texaco?' I continue my enquiry, 'did your father Fernando or other shamans see oil in their yagé visions?' I ask Manatí, who is considered to be the one most acquainted with his father's knowledge. 'Did the inti'ba'ikë know there was a layer of oil in the underground?' I add. Manatí answers no to all my questions and explains they did not know anything about oil before they heard of Texaco and the company started spilling (derramando) oil into their forest and rivers. He also rejects the suggestion that oil should be a wati (a spirit or being) or connected to their agency in any way. While rejecting the idea that oil possesses a form of agency comparable to human beings like other forest- and water-beings do (Vickers 1989b; Krøijer forthcoming), my constant questioning nonetheless compels him to tell the story of the Hikomo-pai, the people with tails who, according to Secoya mythology, live underground. 'As you know,' Manatí begins, 
the Sieko-pai emerged from a hole in the ground near Jupo. There were different people living in the underworld, and the Sieko-pai was living farthest inside the ground [away from the entrance hole]. One day, Nañë [the moon, celestial being involved in the creation of all things] is walking along a forest trail and suddenly he saw a person [pai]. The pai is collecting ya'i [a liana], dragging it behind him into the cave. Nañë steps on the liana, the person keeps pulling from the inside, but then comes out to see why he cannot drag the liana into the hole, if it somehow got stuck. Nañe hides behind a tree, while the pai clears the path and enters to try again. Nañë steps on the liana again and the pai comes out and there he encounters Nañë. "Why are you stepping on my liana, do you want to entrap me?" he asks. "Why are you carrying this liana?" Nañë replies with a counter question. "I am taking it to tie a basket over the fire to smoke chontaduro [palm fruit]," the pai replies. He shows his chontaduro to Nañe, but what he pulls from the basket is not chontaduro, but mud cakes. Nañe looks at it with disgust and says, "This is not chontaduro. I will give you chontaduro." Nañë brings chonta from the forest for him to try. Then all the people living underground get curious; they want to try it too and start coming out of the cave in the ground. They are not Sieko-pai; they have tails, but as they exit Nañë pulls off their tails [and transforms them into various beings of the forest]. Different pai come out, but because we were the furthest back, it was our turn last. A menstruating woman was among the first to appear. She was spilling [derramando] blood on the ground. When he saw her, Nañë got so mad that he transformed her into a deer and hurried to close the hole behind her.

'That is why we are so few,' Manatí ends the story, and adds, 'The hikomo-pai are still living in the underground; they live like Sieko-pai going about their daily activities.' During most of the storytelling, I was only paying partial attention as I had heard it many times before. In this version of the story, however, Manatí was speaking slower and with more emphasis when he reached the last part about the menstruating woman, the spilling of blood, and the disastrous consequences it had for the Secoya. It is considered customary not to hunt or eat the wild deer even though this taboo is seldom upheld anymore, and as Manatí's daughter has once explained, women were seldom held in full seclusion anymore, apart from during the first menstruation and the first day of the menstruation cycle. But what intrigued me most was why he was telling the story in the context of a conversation about oil and oil exploitation on their land. Was it an old man's attempt to get the conversation back on a track that he was surer about or how did the story about the hikomo-pai relate to the question about oil as breach? 
Environmental activist groups in Ecuador have, in the case of the neighbouring Cofán, suggested that oil is the blood of the subterranean Coancoan. This has been used in public campaigning to argue against further oil exploitation by pointing to the catastrophic effects for Cofán life and cosmology (Cepek 2016). Based on Cofán stories about the Coancoan, and the humour and doubt with which the stories are delivered, Michael Cepek convincingly argues in a recent article that to the Cofán the Coancoan pertains to a different realm than contemporary oil exploitation. Rather, according to Cepek, casting the extermination of underworld beings as a consequence of oil exploitation generates a 'sympathetic form of romanticising attention' in public campaigning (ibid.: 623; see also the chapter of $\mathrm{Li}$ and Paredes in this book). Likewise, nothing in Manatí's story about the hikomo-pai, and his comments on the matter, suggest that oil is the blood of the hikomo-pai. The hikomo-pai are-in the knowledge of the Secoya inti'ba'ikë (or shamans, if you will)-the only beings with human-like capacities and forms of life dwelling in the underground, and they have no direct relation to or interaction with oil.

Cepek uses his findings to highlight the pragmatic and epistemological character of the Cofán's discourses about oil as a stepping stone to critique the 'ontological turn' and cosmopolitical research in Latin America, which is accused of reifying and romanticising indigenous struggles. According to Cepek, researchers interested in ontological questions are 'steamrolling the subtleties of their data' and 'constructing a single, homogenized and exoticized conceptual perspective' by not maintaining a relationship to 'accurate ethnography' (ibid.: 624-25). While I agree with the author's conclusion regarding the erroneous characterisation of oil as blood of subterraneous beings, I doubt that it constitutes sufficient grounds for discarding all ontological questions regarding oil as romanticising, or even problematic.

Let me return to Manatí's story and our conversation on the porch. The emphasis on the blood spilled on the ground in the context of a conversation about wehüe (oil as breach and leak) is telling. Among the Secoya-as among many other indigenous peoples of the Amazon basin-the management of menstrual blood and other bodily fluids is considered a delicate process, where the flow between the body and the world has to do with fertility and societal well-being and with managing cosmological insights (Seeger et al. 1979: 11; Belaúnde 2008: 19). In some Amazonian societies, blood is associated with vitality and strength, but more than anything, blood circulates, and this is the source of its properties (ibid.: 38). 
In Secoya communities, blood must be controlled through practices of abstention and seclusion (Belaúnde 2008), though as mentioned before, this is not always strictly followed in practice. A person must control his or her bodily fluids, sometimes with the support of shamans whose power is furthermore essential for securing the flow of game, resisting spirit attacks, and associated sicknesses. Spilled blood can attract dangerous beings such as the jaguar, just as people are attracted by the smell of chicha (ibid.). In my view, therefore, Manatí's story speaks to how oil-which has the property of leaking, flowing, and spilling as the word in pai-koka suggestsmust be contained and controlled like menstruation blood. It is the leakiness of oil (and menstrual blood) that is the only ontological 'essence' at stake. The analytical challenge is, in other words, not to grasp what oil 'really is' (e.g. blood), as a substantivist understanding of the concept of ontology would envisage; rather, it is a point of departure for a new way of thinking about oil: Unintended and uncontrolled flows can, in the case of both oil and of blood, have disastrous effects, as the story's ending with the limited number of Secoya on the surface of the Earth aptly illustrates. It follows that the real matter of concern, especially to inept shamans, as Manatí often refers to himself, and young leaders is how to contain and control such flows. Leaders of indigenous organisations face the difficult task of steering and controlling the flows and unbound qualities of contemporary oil development in Amazonia.

\section{Controlling Unintended Flows}

In the meeting preceding our conversation on the porch, the negotiation strategy vis-à-vis Andes Petrol and the state oil company was hammered out. The pros and cons in economic, political, and existential terms were carefully evaluated (cf. Krøijer 2003). For the first time, wells in the immediate vicinity of where people were living was a likely scenario, and this was not taken lightly. The hope was to ensure a stable flow of money, but avoid the undesired social and environmental effects, including that of having oil workers present in the village all the time.

In the breaks during the meeting, however, people gathered in smaller groups to discuss a series of conspicuous incidents involving the disappearance of outboard motors along the river. When I first conducted fieldwork in this area in 2000, few families owned outboard motors, and it was often necessary to wait for hours or an entire day to catch a lift along the river with a motorised canoe. After accruing compensations from Occidental, 
most families bought at least one motor, which increased traffic on the river significantly. As Hugo jokingly commented, this resulted in the Secoya 'forgetting how to walk' and old paths grew over. But within the second half of 2014, at least 25 motors were stolen, mainly at night, and this was a prime issue of conversation and speculation during gatherings. Hugo had lost one motor, and his aunt, living within the group of houses of their extended family, claimed to have seen a suspicious black canoe steered by a man in a black tunic. The police had little success in their investigations, not doing much apart from patrolling the river accosting people who did not wear a lifejacket in their canoes. Instead of relying on the police investigation, people exchanged views on possible strategies of prevention and containment. Manatí's son-in-law had tied a fierce dog to a pole at the river bank and placed two big lights that illuminated the river at nighttime, to prevent more thefts. The general feeling at the meeting was that it was either Colombians, maybe acting in collusion with the police supposedly investigating the matter, or a bai'ho'wati, the spirit of a particular dead shaman, recognisable because he would usually wear a black tunic, had a bald head, and used a crown made from the ma'so bori flower. According to Manatí, a bai'ho'watí is the most dangerous among spirit-beings as an attack results in almost certain death. Only a strong shaman can repel such an attack from a powerful other, and the Secoya didas everybody knew-no longer count with strong shamans, to which the scarcity of hunting game around San Pablo was also taken as a witness (Krøijer 2017). In this case it was luckily only property being lost, but the discussions over the theft of motors were followed by calls for a stronger 'government' and produced stories about how past shamans had the strength to break and deflect the attacks by foreign shamans. The ongoing speculations at the meeting and beyond made clear how the main concern was with the control of intended and unintended flows of materials and substances that come to leak across the socio-environmental landscape in unintended ways, and it was evident that this concern does not only pertain to some mythic realm but plays out also in relation to contemporary forms of extractivism.

Andes Petrol had two wells in production in an area near another community mostly inhabited by Secoya families that have intermarried with lowland Quichua. According to the oral reports from that village, the construction and oil production was the cause of heavy sedimentation in two small rivers that the community relied on for fishing. Andes Petrol had called for a meeting regarding the new wells the week before, and 
members of their team of community relations had been hanging around the village for cultural events. 'They call themselves our good friends,' Hugo commented with a smile and explicit reference to the Occidentals' 'good neighbour' strategy, 'now I wonder what they mean by that,' he would jokingly comment, not being convinced by their display of good intentions. The president of the Secoya organisation had already sent a letter of complaint to the relevant ministry, demanding that they be appropriately consulted in accordance with ILO Convention no. 169, which had been ratified by Ecuador already in connection to the constitutional reform in 1998. Nonetheless, other members of the community were worried that he might feel tempted to enter into a contract with the company without their knowledge.

Various strategies to steer the flow of money and oil were proposed: one historic leader, who had been involved in forming the first Secoya organisation OISSE but was later accused of spending communal money from Occidental on his own economic ventures, argued at the meeting that the flow of money from companies was too unstable to rely on: 'They drop on us from time to time,' he said in Spanish, 'but then everything returns the same. We become as poor as we were before.' According to him, this had happened in his own case, as the cattle he purchased with money from Occidental had to be slaughtered due to the spread of foot-and-mouth disease and the land around his house was reduced to barren pasture.

He explained that at the time of the missionaries, his father would receive money for work he did for them, but the money was of no use to him. 'Now we never have enough money,' he continued. In his view, the negotiations with Andes Petrol and the state should not be about reparation and compensation; first of all, they needed to 'tell the state how we wish to negotiate with them' and the aim should be 'to participate in all phases of exploration and exploitation, so they pay a direct tax to the community.' This would not only secure a stable flow of money but also more control of the flow. Nevertheless, this strategy did not take environmental damage, land scarcity and degradation into consideration.

To negotiate well, the organisation had armed itself with two US lawyers, remunerated by a new indigenous NGO that is partially funded by the Leonardo DiCaprio Foundation. Where Ecuadorian environmental NGOs had long ago written of the Secoya as too supportive of oil exploitation, these new powerful outsiders were embodying the promise of gaining more control of the process. The two advisors had read the 550-page-long Environmental Impact Study prepared by Andes Petrol, 
and the conclusion they reached was that the report downplayed a number of likely negative impacts. In addition to the letter of complaint regarding the right to consultation, the advisors would prepare another letter to the Ministry of Environment to refute the conclusions and ask for further investigations to be conducted. These two measures would at least buy the Secoya some time to agree among themselves and negotiate the next steps in Andes Petrol's plan.

Not all were equally happy, including the members of Manatí's extended family who, outside the meeting, expressed concerns about the future of the forest but often kept quiet during meetings. Hugo, who was about to finish a university degree, had been bestowed with his grandfather's legacy and received his instruction since childhood. Even though Hugo was not a regular yagé drinker, he described his role as being 'to follow the path of the laid out by his grandfather, through the yagé visions,' but in his own way. Already before ending his university education, he had become the coordinator of the abovementioned indigenous NGO, which mainly comprised young university-educated men and women from the Siona, Secoya, Cofán, and Huaorani nationalities. They want 'to see things done differently,' as Hugo phrased it. The new indigenous NGO was in an ambiguous if not strained relationship with the Secoya organisation and the other representative indigenous organisations, whose presidents were mainly from their paternal generation and from families that used to have closer ties to the Catholic and Pentecostal churches. OISE, which a few years ago changed its name again to NASIEPAI, was still the representative interlocutor on political issues vis-à-vis the state and private companies, but the new young leaders were better educated and were the ones counting on funding from the private climate fund of the famous US actor, Leonardo DiCaprio. In several cases, these new young leaders, such as Hugo, were younger kin of historic shaman-leaders' who often had seen themselves marginalised in the Ecuadorian indigenous movement since its growth to power in the 1990s. The challenge to that power is not only, now, coming from the outside, for example, from oil companies or political parties building alternative NGOs to foster internal divisions (cf. Guzmán-Gallegos 2012) but from within communities and from a new generation. Hugo had gained more presence in the conversations over oil exploitation and for the first time the land issue was placed on the table. Still, the strategy was not one of resistance, but one of delimitation and containment. 
As mentioned, the actual territory is too small to sustain the population, resources are depleted, and the Secoya have experienced a number of invasions of their territory, which the Ministry of Justice had not wished or been able to intervene in or resolve. Hugo suggested that the Secoya should demand land as compensation for oil development and, moreover, that they should undertake a zonificacion, that is, delineate zones in their territory some areas were left untouched by oil development. This both entailed an adoption of modern discourses of forest management, and represented recognition of the fact that it is the state-and not the private companies - that is, the correct interlocutor in the consultation process over further oil development, but also expressed a strong desire to have a land free of oil extraction.

Several Secoya families had for the previous 15 years, with various levels of backing from OISE/NASIEPAI, pressed for the recognition of Secoya ancestral land in Largarto Cocha (Buwëya). This is a pristine river delta on the border between Ecuador and Peru, where the paiche, manatee, and river dolphins are still plentiful. Reclaiming this land would allow the Secoya to create territorial continuity between the Secoya on both sides of the border, but it had not been among the main political priorities of NASIEPAI. After the first demand presented to the Ministry of Environment ten years ago was turned down, based on the fact that the area is now a national park, the issue had not been consistently followed up on. In the meantime, the Peruvian Secoya, the Airo-pai, had gained rights to an extensive territory and established a new community literally on the border between the two countries. Now a generous grant from the Leonardo DiCaprio Foundation had renewed the hope of elders such as Hugo, who continuously talked of Buwëya as the place where he wished to spend his old age. After the meeting Hugo explained in detail:

The Company wants to work in the heart of the area we have for horticulture around San Pablo. This will end our life here. The territory will be without life. For that reason, we want a high-level dialogue with the government, in order for them to compensate us with territory in Buwëya. We are part of the territory and the territory is part of us, and if the territory disappears we will also be without life. We want a territory de'oyo pa'iye, as my grandfather says. This term implies that there is sufficient space to enable a free life, a bealthy territory without conflicts. Lagarto cocha is an alternative to us where you can feel all that [life], which has disappeared from around here. 
According to Hugo, the aspiration was to zone the territory in order to secure a 'healthy part' (una parte de'oyo pa'iye) and thereby allow a healthy flow between body, territory, and outside actors. It also reflects a realisation of the fact that different aspirations coexist among the Secoya and hence different ideas about what a healthy flow looks like. This is continuously rendered visible in the context of debates over further oil development: where some people cast the flow of oil as associated with a potential flow of money, compensation and future jobs, at least if controlled well by the leaders of the organisations, others see oil as the source of undesirable flows and uncontrolled effects. Hugo's rearticulation of the land rights claim and the call for zonificacion of the land within the debate over compensation can be seen as one such way to control and contain the undesirable flows, and to accommodate (in the spirit of oil) the conflicting interests and aspirations that almost always exist in indigenous communities.

\section{ConClusion}

To most indigenous communities in northeastern Ecuador the encounter with extractive industries, particularly oil exploitation on their land, is not a new thing. In this chapter, I have tried to describe how the Secoya, who have lived with oil development in the vicinity of their communities for more than 40 years, talk about and relate to oil or wehüe. I have found that their way of living with oil neither amounts to active and heroic resistance nor to passive acceptance of the conditions imposed on them from the outside. Instead, living with oil concerns the ability to control transformations and leaky flows of crude oil as well as contaminated production water, money, people, and other beings with their own inherent agencies and agendas, while making lives worth living.

In continuation of what I have argued elsewhere (Krøijer 2017), the Secoya seek to 'be flexible' in their encounters with the state, private companies, and other social groups. Being flexible is a strategy for upholding a sense of control and is also tied to the governance of the intended and unintended effects that are inevitably generated by oil exploitation in Amazonia. Whereas oil companies have gone to some lengths to convince the public that negative impacts can be spatially contained (cf. Hindery 2013) - a public argument that in Ecuador has been particularly prevalent in connection to oil exploitation in the Yasuní and in areas inhabited by 
indigenous groups considered to be in voluntary isolation through an argument about the use of tecnología de punta ${ }^{5}$ (Lu et al. 2017; Rival 2016)the concept of wehüe highlights oil's transgressive and transformative potential. Oil exploitation involves flows of oil and production water that sometimes leak into waterways, development of infrastructure and movement of people and workers, flows of goods and money-with potential desirable or undesirable effects - that inevitably leak from the so-called extractive enclaves. I hope to have shown how these leaky flows, which hold the potential for transforming the reality of Amazonian societies, are also the key matters of concern to indigenous groups such as the Secoya.

I have described some of the past and present internal debates about oil, which show that the Secoya do not consider oil to be the blood of subterranean beings, as a parallel ethnography of the Cofán and the subterranean Coancoan also illustrates (Cepek 2016), nor is oil considered a being with agentive qualities that surpass its leakiness. Oil is not a spirit, but instead dealt with 'in the spirit of' oil: oil, according to a Secoya shaman, should be handled as blood, namely as a substance that, if not contained and handled correctly, might disturb the healthy flow between body and territory and powerful 'others' such as states, private companies, jaguars, and spirit-beings (cf. Viveiros de Castro 2012). I have shown that it is probable that the Secoya establish an analogous relationship between oil, blood, and other unintended flows - such as outboard motors being stolen by unknown others-and consider that all such flows should be handled with equal diligence. By asking ontological questions of the material instead of assuming ontological essences, it is possible to appreciate how the only 'essence' of oil is its leakiness; pursuing its analytical implications can reveal the ways in which indigenous communities make their lives with, and in spite of, resource extraction.

Acknowledgements I am grateful to Matthias Borg Rasmussen for stimulating my thinking about resource enclaves. Some of the ideas presented here, I owe to him. I would also like to thank Piergiorgio Di Giminiani, Morten Axel Pedersen, Fabiana Li, the editors of this anthology, and the participants in the LASI Summer School 2018 in Chile for constructive comments and suggestions to earlier versions of this chapter. I thank the CIIR Centre (CONICYT/FONDAP/15110006) at the Pontífica Universidad Católica de Chile for hosting me during the writing process. The research has been made possible thanks to the Danish Council for Independent Research, grant no. 1321-00025B. 


\section{Notes}

1. The language of the Sieko-pai is called pai-koka (literally the language of people/humans). This language has been partly documented by the Summer Institute of Linguistics and the first bilingual Secoya teachers. As in most languages, encounters with new phenomena and changes of habits lead to the development of new words or concepts. Some of the new concepts and words in pai-koka can be found in Nacionalidad Siekopai (NASIEPAI) 2014.

2. Though generally adhering to self-identification as criteria-indigenous peoples in Latin America are generally recognised as the descendants of the precolonial inhabitants of the continent. The United Nation's Declaration on the Rights of Indigenous Peoples (2007) uses the expression of selfdetermination for Indigenous Peoples, but does not grant the right to form independent nation-states. As compensation, indigenous peoples may hold territorial rights within the state, the right to govern internal matters in accordance with their own institutions, and hold the right to be consulted on development plans and initiatives influencing their livelihood. The ILO Convention no. 169 was ratified by Ecuador in 1998, and the UN Declaration on the Rights of Indigenous Peoples was adopted into the new Constitution in 2008.

3. The Siona and Secoya have since the mid-1990s been considered two distinct indigenous peoples, but in Ecuador they have close marriage ties. Between 1942 and 1973, several families lived together in the Cuyabeno River. The majority of Siona today live along the Putumayo in Colombia, whereas the majority of the Secoya live along the Angusilla, Yubineto, Yaricaya, and Huajoya rivers in Peru. Both belong to the Western Tucanoan linguistic group. In the mid-1990s, the indigenous movement in Ecuador, CONAIE, encouraged identification as 'nationalities' (nacionalidades) to push for the recognition of Ecuador as a plurinational state. In this process, the Siona and Secoya, formed independent organisations.

4. There was extensive international news coverage of the 'expulsion' of Occidental from Ecuador, which was generally tied to the attempts of several New Left governments on the continent to 'nationalise' oil. See, for example: http://www.nytimes.com/2006/05/17/business/worldbusiness/17oil. html?mcubz=1

5. High-tech technology, which in the debate over oil exploitation in the Yasuní was claimed to mitigate negative environmental effects such as oil spills. 


\section{REFERENCES}

Barrett, Paul. 2014. Law of the Jungle: The \$19 Billion Legal Battle over Oil in the Rain Forest and the Lawyer Who'd Stop at Nothing to Win. New York: Penguin Random House.

Bebbington, Anthony. 2012. Social Conflict, Economic Development and Extractive Industry: Evidence from South America. London: Routledge.

Bebbington, Anthony, and Jeffrey Bury. 2013. Subterranean Struggles: New Dynamics of Mining, Oil, and Gas in Latin America. Austin: University of Texas Press.

Belaúnde, Luisa. 2008. El recuerdo de la Luna: Género, sangre y memoria entre los pueblos amazónicos. Lima: CAAAP.

Bessire, Lucas. 2014. Behold of the Black Caiman. Chicago/London: University of Chicago Press.

Brunelli, Gilio. 1996. Do Xamanismo aos Xamãs: estratégias Tupi-Mondé frente à sociedade envolvente. In Xamanismo no Brasil: Novas Perspectivas, ed. Esther Jean Langdon. Florianópolis: Editora UFSC.

Casement, Roger. 1913. British Bluebook. Correspondence Respecting the Treatment of British Colonial Subjects and Native Indians Employed in the Collection of Rubber in the Putumayo District. Presented to Both Houses of Parliament by command of His Majesty, July 1912.

Cepek, Michael L. 2009. The Loss of Oil: Constituting Disaster in Amazonian Ecuador. Journal of Latin American and Caribbean Antbropology 17 (3): 393-412.

- 2016. There Might Be Blood: Oil, Humility, and the Cosmopolitics of a Cofán Petro-being. American Ethnologist 43 (4): 623-635.

Ferguson, James. 2005. Seeing Like an Oil Company: Space, Security, and Global Capital in Neoliberal Africa. American Anthropologist 107 (3): 377-382.

Gordillo García, Ramiro. 2005. ¿El Oro Del Diablo? Ecuador: Historia Del Petróleo. Quito: Corporación Editora Nacional.

Gudynas, Eduardo. 2014. Extractivismos: Ecología, economia y politica de un modo de entender el desarrollo y la Naturaleza. Lima: RedGE.

Guzmán-Gallegos, María Antonieta. 2012. The Governing of Extraction, Oil Enclaves, and Indigenous Responses in the Ecuadorian Amazon. In New Political Spaces in Latin American Natural Resource Governance, ed. H. Haarstad. New York: Palgrave Macmillan.

Hardenburg, Walter E. 1913. The Putumayo: The Devil's Paradise: Travels in the Peruvian Amazon Region and an Account of the Atrocities Committed upon the Indians Therein. London: T. Fisher Unwin.

Heywood, Paolo. 2012. Anthropology and What There Is: Reflections on "Ontology". Cambridge Anthropology 30: 143-151. 
Hindery, Derrick. 2013. From Enron to Evo: Pipeline Politics, Global Environmentalism, and Indigenous Rights in Bolivia. Tucson: University of Arizona Press.

Holbraad, Martin, and Morten Axel Pedersen. 2017. The Ontological Turn: An Anthropological Exposition. Cambridge: Cambridge University Press.

Kimerling, Judith. 1993. Crudo Amazonico. Quito: Abya Yala.

Krøijer, Stine. 2003. The Company and the Trickster: A Study of Secoya Storytelling as a Mode of Government. Master's thesis, Department of Anthropology, University of Copenhagen.

- 2017. 'Being Flexible': Reflection on How an Anthropological Theory Spills into the Contemporary Political Lives of an Amazonian People. Tipiti: Journal of the Society for Lowland South America 15 (1): 46-61.

Langdon, Esther Jean. 2016. The Revitalization of Yajé Shamanism Among the Siona: Strategies of Survival in a Historical Context. Anthropology of Consciousness 27: 180-203.

Li, Fabiana. 2015. Unearthing Conflict: Corporate Mining, Activism and Expertise in Peru. Durham/London: Duke University Press.

Lu, Flora, Gabriela Valdivia, and Néstor L. Silva. 2017. Oil, Revolution, and Indigenous Citizenship in Ecuadorian Amazonia. Chicago: University of Illinois Press.

Nacionalidad Siekopai (NASIEPAI) and Gobierno Autónoma Provincial de Sucumbios. 'Plan de Vida Siekopai 2014-2029.' 2014. (unpublished).

Occidental Exploration and Production Company (OEPC). 2000. Convenio para la fase de exploración petrolea en el territorio de la nacionalidad Secoya. (unpublished). http://isis.hampshire.edu/amazon/oil/agree_span.html. Accessed 15 Nov 2017

Payaguaje, Fernando. 1994. In El bebedor de yagé, ed. Miguel Angél Cabodevilla. Quito: CICAME.

Pedersen, Morten Axel. 2012. Common Nonsense: A Review of Certain Recent Reviews of the 'Ontological Turn.' Anthropology of This Century 5. http:// aotcpress.com/articles/common_nonsense/. Accessed 15 Nov 2017.

- 2014. Transitional Cosmologies: Shamanism and Postsocialism in Northern Mongolia. In Framing Cosmologies: The Anthropology of Worlds, ed. Allen Abrahamson and Martin Holbraad. Manchester: Manchester University Press.

Perreault, Tom, and Gabriela Valdivia. 2010. Hydrocarbons, Popular Protest and National Imaginaries: Ecuador and Bolivia in Comparative Context. Geoforum 41 (5): 689-699.

Reider, Susan, and Robert Wasserstrom. 2013. Undermining Democratic Capacity: Myth-Making and Oil Development in Amazonian Ecuador. Ethics in Science and Environmental Politics 13: 39-47.

Rival, Laura. 2016. Huaorani Transformations in Twenty-first-century Ecuador: Treks into the Future of Time. Tucson: University of Arizona Press. 
Rosales, Antulio. 2017. Contentious Nationalization and the Embrace of the Developmental Ideals: Resource Nationalism in the 1970s in Ecuador. The Extractive Industries and Society 4 (1): 102-110.

Santos-Granero, Fernando, and Federica Barclay. 2002. La frontera domesticada: Historia económica y social de Loreto, 1850-2000. Lima: Fondo Editorial de la Pontífica Universidad Católica de Perú.

Sawyer, Suzana. 2001. Frictions of Sovereignty: Of Prosthetic Petro-Capitalism, Neoliberal States and the Phantom-like Citizens in Ecuador. The Journal of Latin American Anthropology 6: 156-197.

- 2004. Crude Chronicles: Indigenous Politics, Multinational Oil and Neoliberalism in Ecuador. Durham: Duke University Press.

- 2015. Crude Contamination: Law, Science, and Indeterminacy in Ecuador and Beyond. In Subterranean Estates: Life Worlds of Oil and Gas, ed. Hannah Appel, Arthur Mason, and Michael Watts. Ithaca: Cornell University Press.

Seeger, Anthony, Roberto da Matta, and Eduardo Viveiros de Castro. 1979. A construção da pessoa nas sociedades indígenas brasileiras. Boletim do Museu Nacional, Série Antropologia 32: 2-19.

Taussig, Michael. 1987. Shamanism, Colonialism, and the Wild Man: A Study in Terror and Healing. Chicago: University of Chicago Press.

Tsing, Anna. 2005. Friction: An Ethnography of Global Connection. Princeton: Princeton University Press.

Vickers, William T. 1989a. Los Sionas y Secoyas: Su adaptación al medio ambiente. Quito: Abya Yala.

- 1989b. Traditional Concepts of Power Among the Siona-Secoya and the Advent of the Nation State. The Journal of Latin American and Caribbean Anthropology 1 (2): 55-60.

- 1998. Informe sobre las negociaciones entre los Secoyas de Ecuador y la Occidental Exploration and Production Company. (unpublished).

Vigh, Henrik, and David Brehm Sausdal. 2014. From Essence Back to Existence: Anthropology Beyond the Ontological Turn. Anthropological Theory 14 (1): $49-73$.

Viveiros de Castro, Eduardo. 1998. Cosmological Deixis and Amerindian Perspectivism. The Journal of the Royal Anthropological Institute 4 (3): $469-488$.

. 2012. Immanence and Fear: Stranger-events and subjects in Amazonía. HAU: Journal of Ethnographic Theory 2 (1): 27-43.

Wasserstrom, Robert. 2014. Surviving the Rubber Boom: Cofán and Siona Society in the Colombia-Ecuador Borderlands (1875-1955). Ethnohistory 61 (3): $525-548$.

Wasserstrom, Robert, and Douglas Southgate. 2013. Deforestation, Agrarian Reform and Oil Development in Ecuador, 1964-1994. Natural Resources 4: $31-44$. 
Weisskoff, Richard, and Edward Wolf. 1977. Linkages and Leakages: Industrial Tracking in an Enclave Economy. Economic Development and Cultural Change 25: 607-628.

Whitten, Norman E. 1978. Amazonian Ecuador: An Interface in Ecological, Social and Ideological Perspectives (Document 34). Copenhagen: IWGIA.

- 1981. Introduction. In Cultural Transformations and Ethnicity in Modern Ecuador, ed. Norman E. Whitten. Urbana: University of Illinois Press.

Wray, Natalia. 2000. Pueblos indigenas amazónicos y actividad petrolera en el Ecuador: conflictos, estrategias e impactos. Quito: IBIS and Oxfam América.

Open Access This chapter is licensed under the terms of the Creative Commons Attribution 4.0 International License (http://creativecommons.org/licenses/ by $/ 4.0 /$ ), which permits use, sharing, adaptation, distribution and reproduction in any medium or format, as long as you give appropriate credit to the original author(s) and the source, provide a link to the Creative Commons license and indicate if changes were made.

The images or other third party material in this chapter are included in the chapter's Creative Commons license, unless indicated otherwise in a credit line to the material. If material is not included in the chapter's Creative Commons license and your intended use is not permitted by statutory regulation or exceeds the permitted use, you will need to obtain permission directly from the copyright holder.

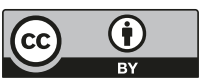

